\title{
Prognosis of breast cancer during pregnancy: evidence for nursing care
}

\author{
Ana Fátima Carvalho Fernandes ${ }^{1}$ \\ Míria Conceição Lavinas Santos ${ }^{2}$ \\ Tiago Barreto de Castro e Silva ${ }^{3}$ \\ Cristina Maria Galvão ${ }^{4}$
}

This integrative review analyzed evidence available in the literature concerning the prognosis of breast cancer during pregnancy. The following databases were used for selecting studies: PubMed, CINAHL and LILACS. A total of 240 primary studies were identified; 13 papers were included in the integrative review's sample after reading the titles and abstracts and according to the established inclusion and exclusion criteria. There is evidence indicating that pregnancy does not worsen the evolution of breast cancer and a poor prognosis is related to late stage tumors. Among the gaps identified in the studied theme, the need for further studies addressing nursing care provided to pregnant women with breast cancer is highlighted in order to promote improved care in the context of health care.

Descriptors: Breast Neoplasm; Pregnancy; Prognosis; Nursing.

\footnotetext{
${ }^{1}$ RN, Ph.D. in Nursing, Associate Professor, Faculdade de Farmácia, Odontologia e Enfermagem, Universidade Federal do Ceará, Fortaleza, CE, Brazil. E-mail: afcana@ufc.br.

${ }^{2}$ RN, Ph.D. in Nursing, Faculdade de Farmácia, Odontologia e Enfermagem, Universidade Federal do Ceará, Fortaleza, CE, Brazil. E-mail: mlavinas@fortalnet.com.br.

${ }^{3}$ RN, M.Sc. in Sciences. E-mail: tiagobcs@live.com.

${ }^{4}$ RN, Ph.D. in Nursing, Full Professor, Escola de Enfermagem de Ribeirão Preto, Universidade de São Paulo, WHO Collaborating Centre for Nursing Research Development, SP, Brazil. E-mail: crisgalv@eerp.usp.br.
}

Corresponding Author:

Cristina Maria Galvão

Universidade de São Paulo. Escola de Enfermagem de Ribeirão Preto

Departamento de Enfermagem Geral e Especializada

Av. dos Bandeirantes, 3900

Bairro: Monte Alegre

CEP: 14040-902, Ribeirão Preto, SP, Brasil

E-mail: crisgalv@eerp.usp.br 


\section{O prognóstico de câncer de mama na gravidez: evidências para o cuidado de enfermagem}

O presente estudo teve como objetivo analisar as evidências disponíveis na literatura sobre o prognóstico de câncer de mama na gravidez. O método de revisão adotado foi a revisão integrativa. Para a seleção dos estudos primários, utilizaram-se as bases de dados PubMed, CINAHL e LILACS. Na busca, foram identificados 240 estudos primários, após a leitura dos títulos e resumos e, frente aos critérios de inclusão e exclusão estabelecidos, 13 artigos foram incluídos na amostra da revisão integrativa. Na síntese do conhecimento produzido, há evidências que indicam que a gestação não piora a evolução do câncer de mama e o mau prognóstico está relacionado ao estadiamento tardio do tumor. Dentre as lacunas identificadas, sobre o tópico investigado, destaca-se a necessidade de condução de estudos direcionados para a assistência de enfermagem, prestada à mulher grávida, com câncer de mama, para promover a melhoria do cuidado no contexto da atenção à saúde.

Descritores: Neoplasias da Mama; Gravidez; Prognóstico; Enfermagem.

\section{El pronóstico de cáncer de mama en el embarazo: evidencias para la atención de enfermería}

Esta revisión integradora de la literatura objetivó analizar las evidencias disponibles en la literatura sobre el pronóstico del cáncer de mama durante el embarazo. La selección de los estudios primarios fue realizada en las bases de datos PubMed, CINAHL y LILACS; se identificaron 240 estudios primarios. Después de la lectura de los títulos y resúmenes y establecimiento de los criterios de inclusión y exclusión, 13 artículos fueron incluidos en la muestra de la revisión integradora. En la síntesis del conocimiento producido hay evidencias que indican que el embarazo no empeora la evolución del cáncer de mama y el pronóstico malo está relacionado con la estadificación clínica tardía del tumor. Entre las lagunas en el tópico investigado hay que resaltar la necesidad de realizar estudios sobre la atención de enfermería prestada a mujeres embarazadas con cáncer de mama para mejoría del cuidado en el contexto de la atención a la salud.

Descriptores: Neoplasias de la Mama; Embarazo; Pronóstico; Enfermería.

\section{Introduction}

One of the problems that most seriously affects women in all aspects of life is the diagnosis of breast cancer, which is probably the most feared diagnosis among the female population given its increased incidence and the psychological and social impact it causes, especially due to the atmosphere of fear and taboo that surround such a disease ${ }^{(1)}$.

According to estimates published by the Brazilian Cancer Institute (INCA), the number of new cases of breast cancer expected for Brazil in 2010 is 49,240, with an estimated risk of 49.27 cases/100,000 women. The estimates present a total of 8,270 new cases for the northeast: 550 new cases are estimated to be diagnosed in Paraiba and 210 in the capital of the state, which amounts to raw rates of $28.68 / 100,000$ and 59.34/100,000, respectively ${ }^{(2)}$.

Conducting studies in this context is relevant, especially studies producing evidence to fill in gaps of knowledge concerning the issue, specifically pregnancyassociated breast cancer (PABC), which is addressed in this study.

PABC is every breast cancer diagnosed during pregnancy or up to one year after birth. The first reports of this disease, date to more than a hundred years ago and had a poor prognosis. The first researchers published a case series and after five years of follow-up, all patients died(3). 
A study published in 1999 indicated that breast cancer accounts for $0.2 \%$ to $3.8 \%$ of all cancers affecting women during pregnancy, with a ratio from $1 / 3,000$ to $1 / 10,000$ pregnancies(4). Another study reported that depending on the country, some case series presented an association of $1 / 2,000$ pregnancies ${ }^{(5)}$. PABC is the second most frequent cause of neoplasia associated with pregnancy, surpassed only by cervical cancer ${ }^{(4,6)}$.

Over the course of our careers, we have developed activities with groups of women with cancer, including women who were undergoing treatment and became pregnant or who became pregnant after a cancer diagnosis and those who within five years due to the pathology. From this experience emerged the need to research the prognosis of PABC.

Given the preceding discussion, we believe this study provides support based on the results of studies that can help decision-making of nurses aiming to improve care provided to women with breast cancer.

\section{Objective}

To analyze evidence available in the literature on the prognosis of PABC.

\section{Method}

Evidence-based practice (EBP) involves the definition of a problem, the search for and critical evaluation of available evidence, implementation of evidence in practice and evaluation of the results obtained. The clinical expertise of professionals and patients' preferences are aspects that are also incorporated into the EBP for decision-making concerning health care(7).

The method chosen to achieve the proposed objective in this study was an Integrative Review (IR), which considerably contributes to strengthening EBP.

The following stages were followed: identification of the theme or development of the guiding question, sampling or search of studies in the literature, categorization of studies, evaluation of studies included in the review, discussion and interpretation of results, and synthesis of knowledge found in the analyzed papers or the presentation of the integrative review's results ${ }^{(8)}$.

The guiding question used in this integrative review was: "What is the evidence available in the literature concerning the prognosis of PABC?"

The following databases were used to search for primary studies: PUBMED-MEDLINE (Medical Literature Analysis and Retrieval System on-line), CINAHL (Cumulative Index to Nursing and Allied Health
Literature) and LILACS (Latin-American and Caribbean Health Sciences).

The controlled and non-controlled descriptors (key words) selected for the primary studies search are listed in Figure 1, which were combined and/or modified in each database according to the need to ensure a comprehensive search.

\begin{tabular}{|c|c|c|}
\hline Databases & Controlled descriptors & $\begin{array}{c}\text { Non-controlled } \\
\text { descriptors }\end{array}$ \\
\hline \multirow{3}{*}{ PUBMED } & Pregnancy & \multirow{3}{*}{ Breast cancer } \\
\hline & Breast neoplasms & \\
\hline & Prognosis & \\
\hline \multirow{3}{*}{ LILACS } & Pregnancy & \multirow{3}{*}{ Breast cancer } \\
\hline & Breast neoplasms & \\
\hline & Prognosis & \\
\hline \multirow{3}{*}{ CINAHL } & Breast neoplasms & \multirow{3}{*}{ Breast cancer } \\
\hline & Prognosis & \\
\hline & Pregnancy & \\
\hline
\end{tabular}

Figure 1 - Controlled and non-controlled descriptors according to the selected databases

Inclusion criteria to select primary studies were: papers addressing breast cancer during pregnancy, published in English, Spanish or Portuguese in the last ten years (January 2000 up to April 2010). Literature reviews or narrative reviews and editorials were excluded.

Primary studies were selected by title and abstract according to the study's objective and adopted inclusion and exclusion criteria. A total of 178 papers were preselected from PUBMED, 26 from LILACS, and 36 from CINAHL, totaling 240 papers.

A total of 26 papers were drawn from those primary studies pre-selected from PUBMED after a fresh reading, from which 17 were excluded. Hence, nine papers from this database were included in the review. Only two papers from the 26 pre-selected from LILACS were included. Six primary studies were identified in CINAHL but they were all excluded. Therefore, the IR sample was composed of 13 papers, which were fully analyzed.

A data collection instrument proposed and validated by Ursi( ${ }^{(9)}$ was used to extract data. Concepts proposed by researchers from the nursing field were used to analyze the studies' design and level of evidence of the primary studies included in the review ${ }^{(10-11)}$.

The analysis and synthesis of the primary studies were performed in a descriptive form, allowing readers to evaluate the quality of evidence (level of evidence) 
available in the literature concerning the investigated theme, support decision-making in daily nursing care provided to patients with PABC and also identify gaps of knowledge for the development of future research.

\section{Results}

Ten out of the 13 papers included in the review were published in English, two in Portuguese and one in Spanish. Publications originated from many different countries and the Irish Medical Journal stood out with two papers.

In relation to papers' level of evidence: seven primary studies presented level of evidence IV, that is, case-control studies; five studies presented level of evidence VI: one descriptive, two case series, one retrospective and a case study; one study presented level of evidence VII: expert opinion. Figure 2, 3 and 4 present an abstract of each paper included in the IR and Figure 5 presents the synthesis of primary studies concerning the investigated outcome (prognosis).

\begin{tabular}{|c|c|c|c|}
\hline Study & Objective & Result & Conclusion \\
\hline Gelber et al. ${ }^{(12)}$ & $\begin{array}{l}\text { To evaluate the impact of a } \\
\text { pregnancy subsequent to diagnosis } \\
\text { on the prognosis of patients with } \\
\text { breast cancer in its initial stage. }\end{array}$ & $\begin{array}{l}\text { The survival of women who became } \\
\text { pregnant was greater than that of the } \\
\text { compared group, for whom the five- } \\
\text { year survival rate was } 85 \% \pm 3 \% \text { and } \\
\text { ten-year survival rate was } 74 \% \pm 4 \% \text {. }\end{array}$ & $\begin{array}{l}\text { Pregnancy subsequent to diagnosis } \\
\text { did not adversely affect the prognosis } \\
\text { of breast cancer in its initial stage. } \\
\text { The greater survival observed } \\
\text { in this study and in others may } \\
\text { merely reflect a selection bias of } \\
\text { healthy patients, though it is also } \\
\text { consistent with the antitumor effect of } \\
\text { pregnancy. }\end{array}$ \\
\hline Mottola-Junior et al..$^{(13)}$ & $\begin{array}{l}\text { To study } 15 \text { cases of PABC and } \\
\text { compare them with a control group } \\
\text { of young patients with invasive } \\
\text { ductal carcinoma, evaluating } \\
\text { the clinical stage, axillary lymph } \\
\text { node involvement, nuclear grade, } \\
\text { histological tumor grade, and } \\
\text { hormone receptors for estrogen and } \\
\text { progesterone. }\end{array}$ & $\begin{array}{l}\text { In relation to disease-free survival } \\
\text { and global survival: nine patients } \\
(60 \%) \text { were alive and free of disease, } \\
\text { four patients }(26.6 \%) \text { were alive } \\
\text { with the disease, and two ( } 13.4 \%) \\
\text { patients died. A statistically significant } \\
\text { difference was found for the worst } \\
\text { clinical stage ( } p=0.0022) \text { and greater } \\
\text { axillary lymph node involvement } \\
(p=0.0017) \text { in pregnant women. }\end{array}$ & $\begin{array}{l}\text { There was no difference when } \\
\text { pregnant women were compared } \\
\text { to non-pregnant women within the } \\
\text { same age range in relation to the } \\
\text { prognosis of PABC. }\end{array}$ \\
\hline Reed et al. ${ }^{(14)}$ & $\begin{array}{l}\text { To evaluate prognosis factors in } \\
173 \text { patients with breast cancer } \\
\text { subdivided into three groups: } \\
\text { subsequent group, pregnancy group } \\
\text { and breastfeeding group. }\end{array}$ & $\begin{array}{l}\text { None of the studied parameters were } \\
\text { significant predictors of prognosis } \\
\text { when compared to breastfeeding }+ \\
\text { pregnancy versus subsequent group. } \\
\text { Being } 35 \text { years old or younger was } \\
\text { an unfavorable prognosis factor only } \\
\text { for the breastfeeding + pregnancy } \\
\text { groups. Five-year survival was } 40 \% \text {, } \\
41 \% \text { and } 86 \% \text { in the pregnancy, } \\
\text { breastfeeding and subsequent } \\
\text { groups respectively. }\end{array}$ & $\begin{array}{l}\text { The results demonstrated that } \\
\text { breastfeeding (birth } 1-12 \text { months } \\
\text { before the breast cancer diagnosis) } \\
\text { and pregnancy (birth } 0-9 \text { months } \\
\text { after diagnosis) groups were } \\
\text { very similar in relation to clinical- } \\
\text { pathological parameters compared } \\
\text { to the subsequent group (birth more } \\
\text { than } 9 \text { months after diagnosis), with } \\
\text { larger tumors, greater histological } \\
\text { classification, negative status } \\
\text { for hormonal receptors and high } \\
\text { positivity for c-erb-2. }\end{array}$ \\
\hline Aziz et al..$^{(15)}$ & $\begin{array}{l}\text { To measure the various tumor } \\
\text { markers (p53, C-erb-2, EGFR, } \\
\text { Cathepsin-D, PCNA, DNA ploidy } \\
\text { and S-phase fraction) jointly with } \\
\text { the development of the disease in } \\
\text { patients with PABC compared to a } \\
\text { control group. }\end{array}$ & $\begin{array}{l}\text { All the patients (case and control } \\
\text { groups) had been diagnosed with } \\
\text { infiltrating ductal carcinoma. No } \\
\text { statistically significant difference was } \\
\text { found in relation to global survival of } \\
\text { tested patients and the control group, } \\
\text { if compared stage by stage. }\end{array}$ & $\begin{array}{l}\text { Malignant neoplasms of the breast } \\
\text { may not be noticed for varying } \\
\text { periods of time, which gives them } \\
\text { a chance to increase in size before } \\
\text { detection, leading to a larger } \\
\text { tumor size found in PABC patients. } \\
\text { Additionally, lymph nodes metastasis } \\
\text { is common in these patients, again } \\
\text { due to a delay in diagnosing it, which } \\
\text { directly affects the prognosis. }\end{array}$ \\
\hline
\end{tabular}


(continuation)

\begin{tabular}{|c|c|c|c|}
\hline Study & Objective & Result & Conclusion \\
\hline Makgasa et al. ${ }^{(16)}$ & $\begin{array}{l}\text { To evaluate the experience of a } \\
\text { facility specializing in breast cancer } \\
\text { treatment in the north of Ireland in } \\
\text { dealing with PABC. }\end{array}$ & $\begin{array}{l}\text { The average age of PABC patients } \\
\text { was } 36.58 \text { years old and that of } \\
\text { those in the control group was } 37.96 \text {. } \\
\text { Eleven PABC patients presented } \\
\text { localized disease; one presented } \\
\text { bone metastasis; one had bloody } \\
\text { breast discharge; and all the } \\
\text { remaining presented a palpable } \\
\text { lump. The average time of pregnancy } \\
\text { at the time of the diagnosis was } 15.5 \\
\text { weeks. All the patients underwent } \\
\text { surgery and all PABC patients had a } \\
\text { moderate to poor clinical prognosis } \\
\text { according to the Nottingham } \\
\text { Prognostic Index. }\end{array}$ & $\begin{array}{l}\text { The poor diagnosis for PABC } \\
\text { patients may be related to a late } \\
\text { diagnosis or delayed search for } \\
\text { services. Another hypothesis is } \\
\text { that the biology of PABC patients is } \\
\text { inherently more aggressive. In fact, } \\
\text { the PABC patients belatedly sought } \\
\text { for health care and the disease } \\
\text { was already advanced when the } \\
\text { prognosis is usually poor. }\end{array}$ \\
\hline Halaska et al.(17) & $\begin{array}{l}\text { To describes the epidemiology, } \\
\text { treatment and development of } \\
\text { women diagnosed with PABC or } \\
\text { within one year after pregnancy. }\end{array}$ & $\begin{array}{l}\text { No statistically significant difference } \\
\text { was found in relation to survival rate } \\
\text { comparing the PABC group and the } \\
\text { control group (non-pregnant women) } \\
(p=0.449) \text {. }\end{array}$ & $\begin{array}{l}\text { Stage by stage, the prognosis of } \\
\text { breast cancer is similar if comparing } \\
\text { PABC women and non-PABC } \\
\text { women, though poorer diagnoses } \\
\text { in the postpartum should be } \\
\text { investigated. }\end{array}$ \\
\hline Beadle et al. ${ }^{(18)}$ & $\begin{array}{l}\text { To compare the rates of locoregional } \\
\text { recurrence, metastases and survival } \\
\text { in young patients ( } 35 \text { years old or } \\
\text { younger) who developed PABC to } \\
\text { non-PABC women. }\end{array}$ & $\begin{array}{l}\text { No statistically significant difference } \\
\text { was found between PABC and } \\
\text { non-PABC women in relation to } \\
\text { rates of locoregional recurrence, } \\
\text { distant metastasis rates and ten- } \\
\text { year survival. A greater proportion } \\
\text { of lymph vascular invasion was } \\
\text { observed in the PABC group while } \\
\text { no statistically significant differences } \\
\text { were found within this group (cancer } \\
\text { during or up to one year after } \\
\text { pregnancy). }\end{array}$ & $\begin{array}{l}\text { The fact that PABC patients present } \\
\text { a more advanced stage suggests } \\
\text { that the greater risk for this group } \\
\text { results from a delayed diagnosis } \\
\text { since the pregnancy by itself } \\
\text { does not imply a poor diagnosis. } \\
\text { A pregnancy may, however, mask } \\
\text { the symptoms and hinder an early } \\
\text { diagnosis. }\end{array}$ \\
\hline
\end{tabular}

Figure 2 - Synthesis of studies with level of evidence IV (case-control)

\begin{tabular}{|c|c|c|c|c|}
\hline Author & Study design & Objective & Results & Conclusion \\
\hline $\begin{array}{l}\text { Peralta- } \\
\text { Musre }^{(19)}\end{array}$ & Descriptive study & $\begin{array}{l}\text { To describe the profile of } \\
\text { women enrolled in a breast } \\
\text { pathology unit from a } \\
\text { gynecological and obstetrical } \\
\text { service in a hospital in relation } \\
\text { to pregnancy and breast cancer. }\end{array}$ & $\begin{array}{l}\text { Three-, four-, or ten-year } \\
\text { disease-free survival was lower } \\
\text { than that of non-pregnant } \\
\text { women. }\end{array}$ & PABC prognosis is usually poor. \\
\hline Hill et al. ${ }^{(20)}$ & Case series & $\begin{array}{l}\text { To analyze the clinical evolution } \\
\text { of } 12 \text { women with PABC history. }\end{array}$ & $\begin{array}{l}\text { In the analysis of clinical } \\
\text { evolution of the studied cases: } \\
\text { five patients died and two } \\
\text { already had metastatic disease } \\
\text { at the time of diagnosis. Median } \\
\text { of survival was } 31 \text { months. } \\
\text { There were three stillbirths: one } \\
\text { therapeutic abortion and two } \\
\text { during chemotherapy treatment. }\end{array}$ & $\begin{array}{l}\text { A PABC diagnosis is difficult } \\
\text { and usually occurs in advanced } \\
\text { stages. Surgery may safely be } \\
\text { performed during pregnancy } \\
\text { and adjuvant chemotherapy } \\
\text { should not be postponed until } \\
\text { postpartum }\end{array}$ \\
\hline $\begin{array}{l}\text { Grossmann et } \\
\text { al. }{ }^{(21)}\end{array}$ & Retrospective study & $\begin{array}{l}\text { To retrospectively evaluate } 86 \\
\text { surgical specimens of women } \\
\text { who underwent surgery and } \\
\text { were cared for in the Institute of } \\
\text { Tumors in Milan between } 1977 \\
\text { and } 1991 \text { and their relationship } \\
\text { to relative risk of death through } \\
\text { the variables: tumor, nodes, age. }\end{array}$ & $\begin{array}{l}\text { The results show the level } \\
\text { of statistical significance for } \\
\text { the variables of association } \\
\text { by order of importance: } \\
\text { histological classification of } \\
\text { tumor size, axillary lymph node } \\
\text { histopathologic classification } \\
\text { and age. }\end{array}$ & $\begin{array}{l}\text { Based on the studied variables, } \\
\text { the authors concluded that } \\
\text { the use of the product of the } \\
\text { variables tumor histopathologic } \\
\text { classification, number of } \\
\text { involved axillary lymph nodes } \\
\text { and age permit predicting with } \\
\text { statistical significance relative } \\
\text { risk of death for each patient } \\
\text { with breast neoplasm during } \\
\text { pregnancy. }\end{array}$ \\
\hline
\end{tabular}


(continuation)

\begin{tabular}{|c|c|c|c|c|}
\hline Author & Study design & Objective & Results & Conclusion \\
\hline $\begin{array}{l}\text { Martínez- } \\
\text { Ramos et } \\
\text { al. }{ }^{(22)}\end{array}$ & Case study & $\begin{array}{l}\text { To describe a case of a } 34 \\
\text { years old woman, in the } 28 \text { th } \\
\text { week of pregnancy, who sought } \\
\text { the health service given a lump } \\
\text { in the right breast. }\end{array}$ & $\begin{array}{l}\text { After clinical exams and biopsy, } \\
\text { the patient was diagnosed with } \\
\text { breast cancer and underwent } \\
\text { a Madden modified radical } \\
\text { mastectomy. The patient } \\
\text { underwent a C-section in the } \\
32^{\text {nd }} \text { week and began later the } \\
\text { usual chemotherapy treatment. }\end{array}$ & $\begin{array}{l}\text { The authors state that PABC } \\
\text { is a frequent and common } \\
\text { disease but not exceptional. } \\
\text { They highlight the importance } \\
\text { of a high rate of early detection } \\
\text { of breast lumps, which leads to } \\
\text { early diagnosis, consequently } \\
\text { improving the patient's } \\
\text { prognosis. }\end{array}$ \\
\hline $\begin{array}{l}\text { Khairy, Al- } \\
\text { Abdulkarim }^{(23)}\end{array}$ & Case series & $\begin{array}{l}\text { To describe the clinical evolution } \\
\text { of five women with PABC. }\end{array}$ & $\begin{array}{l}\text { Three patients were diagnosed } \\
\text { in the first trimester of pregnancy } \\
\text { and two postpartum (two weeks } \\
\text { and } 9 \text { months later). One of } \\
\text { them underwent therapeutic } \\
\text { abortion. One patient was } \\
\text { diagnosed in stage II and four in } \\
\text { stage III. All patients presented } \\
\text { some lymph node involvement } \\
\text { but none were diagnosed with } \\
\text { metastatic disease. All women } \\
\text { were treated with adjuvant } \\
\text { chemotherapy after surgery. } \\
\text { One died. }\end{array}$ & $\begin{array}{l}\text { Diagnosing PABC is difficult } \\
\text { because physiological changes } \\
\text { during this period hinder its } \\
\text { detection. Greater attention } \\
\text { should be paid toward improving } \\
\text { care standards, especially in } \\
\text { regions where the diagnosis is } \\
\text { usually delayed. }\end{array}$ \\
\hline
\end{tabular}

Figure 3 - Synthesis of studies with level of evidence VI

\begin{tabular}{|c|l|l|}
\hline \multicolumn{1}{|c|}{ Study } & \multicolumn{1}{|c|}{ Expert opinion } & \multicolumn{1}{c|}{ Conclusion / Recommendations } \\
\hline Loibl et al. ${ }^{(24)}$ & $\begin{array}{l}\text { Report of an expert committee } \\
\text { concerning PABC. }\end{array}$ & $\begin{array}{l}\text { The objective of treatment provided to PABC women is the same as that provided } \\
\text { to non-pregnant women: local control of the disease and prevention of metastases. } \\
\text { However, certain types of treatment need to be modified given the potential } \\
\text { adverse effects posed to the fetus. There is evidence that supports the safe use of } \\
\text { chemotherapeutic anthracycline during the second and third trimesters of pregnancy } \\
\text { (level of evidence Oxford } 2 \mathrm{~b}) \text {. Due to a lack of evidence concerning the routine use } \\
\text { of new cytotoxic drugs such as taxanes, experts did not recommend their use during } \\
\text { pregnancy. }\end{array}$ \\
\hline
\end{tabular}

Figure 4 - Synthesis of study with level of evidence VII

\begin{tabular}{|c|c|c|}
\hline Year & Authors & Outcome \\
\hline 2001 & Gelber et al. ${ }^{(12)}$ & $\begin{array}{l}\text { There are no adverse effects of pregnancy subsequent to diagnosis in the prognosis of PABC women and } \\
\text { there is evidence that a pregnancy may be actually associated to a more favorable prognosis. }\end{array}$ \\
\hline 2001 & Peralta-Musre ${ }^{(19)}$ & $\begin{array}{l}\text { The prognosis of PABC is usually unfavorable due to delay in diagnosis and treatment. The studied } \\
\text { patients presented lower five-year survival than non-pregnant women. }\end{array}$ \\
\hline 2002 & Hill et al. ${ }^{(20)}$ & $\begin{array}{l}\text { Even though stage-by-stage prognosis is similar, PABC has a worse general prognosis than when breast } \\
\text { cancer does not occur in this period; delay in diagnosing the disease may contribute to it. }\end{array}$ \\
\hline 2002 & Mottola- Júnior et al. ${ }^{(13)}$ & $\begin{array}{l}\text { PABC has a poor prognosis and no differences were found when non-pregnant women within the same } \\
\text { age range were compared with PABC women. The determinant factor for survival is the advanced clinical } \\
\text { stage at the time of diagnosis. }\end{array}$ \\
\hline 2002 & Grossmann et al. ${ }^{(21)}$ & $\begin{array}{l}\text { Young pregnant and non-pregnant women with breast cancer tend to have a worse prognosis than } \\
\text { premenopausal or postmenopausal women. Axillary involvement is an important element in staging and } \\
\text { prognosis. }\end{array}$ \\
\hline 2003 & Reed et $\mathrm{al}^{(14)}$ & $\begin{array}{l}\text { The authors state that PABC prognosis is poor, though the reasons for that are still unknown. Also, the } \\
\text { shorter the time between cancer diagnosis and a previous pregnancy, the worse the prognosis. }\end{array}$ \\
\hline 2003 & Aziz et al ${ }^{(15)}$ & $\begin{array}{l}\text { The results did not present a statistically significant difference between the PABC group and the control } \\
\text { group in regard to survival and late staging. }\end{array}$ \\
\hline
\end{tabular}


(continuation)

\begin{tabular}{|c|c|c|}
\hline Year & Authors & Outcome \\
\hline 2006 & Loibl et al. ${ }^{(24)}$ & $\begin{array}{l}\text { The authors state that the prognosis for PABC patients does not seem to differ from that of non-pregnant } \\
\text { women within the same age range and stage of disease. }\end{array}$ \\
\hline 2007 & Martínez-Ramos et al. ${ }^{(22)}$ & $\begin{array}{l}\text { The authors claim that the poor prognosis of PABC women is probably related to the advanced tumor } \\
\text { stage at the time of diagnosis and state that the prognosis of these women is similar to that of non- } \\
\text { pregnant women when compared by age and tumor stage. Five-year survival is approximately } 60 \% \text { when } \\
\text { there are no lymph node metastases and } 45 \% \text { when nodes are not affected. }\end{array}$ \\
\hline 2008 & Khairy, Al-Abdulkarim ${ }^{(23)}$ & $\begin{array}{l}\text { The authors indicate that a worse prognosis frequently occurs given a late diagnosis. Stage-by-stage } \\
\text { prognosis of PABC is similar to that of non-pregnant women. }\end{array}$ \\
\hline 2009 & Makgasa et al. ${ }^{(16)}$ & $\begin{array}{l}\text { This study demonstrated that PABC is presented with large tumors with significant involvement of lymph } \\
\text { nodes and moderate to poor prognosis. }\end{array}$ \\
\hline 2009 & Halaska et al. ${ }^{(17)}$ & $\begin{array}{l}\text { Based on the case series, the authors assert there was a tendency toward a worse prognosis when PABC } \\
\text { was diagnosed within a year after birth. }\end{array}$ \\
\hline 2009 & Beadle et al. ${ }^{(18)}$ & $\begin{array}{l}\text { Poorer prognoses related to breast cancer are much more related to the young age of patients than to } \\
\text { pregnancy. Patients with PABC do not have a poor prognosis if diagnosed during pregnancy or within one } \\
\text { year postpartum. }\end{array}$ \\
\hline
\end{tabular}

Figure 5 - Synthesis of primary studies concerning studied outcome (prognosis)

\section{Discussion}

From the synthesis of evidence of the primary studies included in the review concerning the prognosis of PABC, we stress that nine out of the 13 studies included indicate that a poor prognosis is associated to late stage tumors ${ }^{(13-15,16-17,20-23)}$.

A previous study had already indicated that poor prognoses are related to the time between the breast cancer diagnosis and pregnancies preceding the diagnosis $^{(25)}$. One recent study also indicates that one of the issues that complicate the prognosis of breast cancer during pregnancy is a delayed diagnosis(26). Poor prognoses are partially explained by the tendency of pregnant women to be in more advanced stages of the disease at the time of the diagnosis. Still, that does not seem to be the only explanation since there is also a study indicating that the pregnancy itself is an independent factor for a worse prognosis(27).

A study published in 1999 reports that the survival of patients in the stages II or III was $75 \%$, suggesting that with modern therapy and multidisciplinary help, the prognosis would not be so poor as once believed(4). On the other hand, in two studies included in the integrative review, the results did not show statistically significant difference concerning survival rate in a comparison between PABC women and the control group (nonpregnant women) $)^{(17-18)}$.

The authors of another study claim that pregnancy hormones would be responsible for a worse prognosis. Pregnancy is characterized by a significant increase of estrogen, IGF-1, progesterone and prolactin, which in turn are closely related to the etiology of breast cancer and its development. These hormones promote the growth of tumor cells responsive to hormones ${ }^{(28)}$.

It became clear in cell culture that the increase of hormone concentrations during pregnancy can increase the proliferation of cancer cells and tumor size. Another hypothesis that would explain the high mortality of pregnant women with breast cancer is that pregnancy hormones select tumors with a worse prognosis. But there are few studies addressing the topic(29-31).

An immunohistochemistry study conducted over more than 700 cases of breast cancer reported that tumors of women who had recently gave birth did not differ in size, staging or receptors of estrogen and HER2 but did present more progesterone receptornegative, positive p53 and a greater histological degree. Hence, progesterone receptor-negative seems to be associated with a worse prognosis, in part because it is less sensitive to tamoxifen and also because it confers an invasive phenotype on the tumor cells in a model system. A greater expression of p53 in pregnant women with breast cancer is also consistent in the selection of more aggressive tumors during pregnancy(29).

There is evidence in the literature indicating that a pregnancy does not worsen the evolution of breast cancer, according to five primary studies included in the review ${ }^{(12,15,22-24)}$. The authors report that the prognosis of PABC women does not seem to differ from that of non-pregnant women within the same age range and who are at the same disease stage. These results are corroborated by two other studies(32-33). Two studies in the review indicate a poor prognosis for breast cancer 
patients when associated with young age, stating that young women with breast cancer, pregnant or not, tend to have a worse prognosis ${ }^{(18,21)}$.

One of the aspects that complicate the prognosis of PABC is a delayed diagnosis. In this context, one should take into account the physiological changes caused by the pregnancy in the mammary glands related to consistency and density, which may mask the disease's signs and symptoms and hinder a precise interpretation of screening exams, delaying diagnosis and consequently reducing the rates of the survival of these women ${ }^{(26)}$. It is common in professional practice to encounter painless lumps that can go unnoticed due to the breasts' increased volume and engorgement. Hence, the nurses' preparedness to perform physical assessments, especially of the breasts during prenatal care and postpartum, is a relevant element that can contribute to the early detection of PABC.

The studied problem may be a result of inappropriate care that presents gaps mainly in prenatal care. Quality and humanized prenatal and postpartum care is essential for the health of mother and child. For care to be qualified and humanized, one has to look at the health-disease continuum from a new perspective and understand the person in her totality of body and mind and also consider the social, economic, cultural and physical environment where she is inserted. Moreover, new bases should be established for the relationships of those involved in the production of health: health professionals, users and managers ${ }^{(34)}$.

It is the role of nurses to implement integral and multidisciplinary care for women experiencing breast cancer during pregnancy, intensifying continuous and individualized evaluation during prenatal care, acknowledging the participation of women and families in decision-making concerning the treatment and maintenance of pregnancy, and considering ethical, religious, psychological, organic and legal aspects ${ }^{(35)}$.

\section{Conclusion}

The synthesis of knowledge produced in this integrative review indicates there is evidence in the literature that a pregnancy does not worsen the evolution of breast cancer and that the poor diagnosis is related to the late stage tumors. However, given the reduced number of papers included in the analysis and their level of evidence (IV, VI and VII) further studies addressing the topic are needed.

The conduct of this integrative review reinforced the importance of early diagnosis, which can contribute to an improved prognosis for PABC women. In this context, we highlight the role of nurses since the results from this review support decision-making of nurses concerning the planning and implementation of interventions in nursing care provided to this population.

Nurses working with care delivered to women at all levels of care need to implement strategies to intensify preventive actions and the early detection of breast cancer, especially during pregnancy, and develop actions directed to primary care. The qualification of nurses to perform physical assessments, especially of breasts during prenatal and postpartum care, is a relevant contribution to the early detection of PABC.

Among the required actions, we highlight health education actions in which nurses should encourage an active role of women using the health services, stimulating breast self-examination. Nursing has a preponderant role in developing actions jointly with the population since the focus of its work is humanized care, centered on disease prevention of and health promotion.

Finally, among the gaps identified in the studied topic, we underscore the need to conduct studies addressing nursing care provided to PABC women in order to promote improved health care.

\section{References}

1. Fernandes AFC, Mamede MV. Câncer de mama: mulheres que sobreviveram. Fortaleza (CE): Universidade Federal do Ceará; 2003. 93 p.

2. Brasil. Ministério da Saúde. Instituto Nacional de Câncer. Estimativa 2010: incidência de câncer no Brasil / Instituto Nacional de Câncer. Rio de Janeiro: INCA, 2009. 98p.

3. Kilgore AR, Bloodgood JC. Tumors and tumor-like lesions of the breast in association with pregnancy. Arch Surg. 1929;18(5):2079-98.

4. Berry DL, Theriaut RL, Holmes FA, Parisi VM, Booser DJ, Singletary SE, et al. Management of breast cancer during pregnancy using a standardized protocol. J Clin Oncol.1999;17(3):881-55.

5. Gemignani M, Petrek J, Borgen P. Breast cancer and pregnancy. Surg Clin North Am. 1999; 79(5):1157-69.

6. Brewster WR, Disaia PJ. Breast cancer associated whit pregnancy. In: Winchester DJ, Winchester DP, editors. Atlas of clinical oncology: breast cancer. London: Hamilton; 2000.p.258-259.

7. Galvão CM, Sawada N, Rossi LA. A prática baseada em evidências: considerações teóricas para a sua implementação na enfermagem perioperatória. Rev Latino-am Enfermagem 2002;10(5):690-5.

8. Mendes KD, Silveira RCCP, Galvão CM. Revisão integrativa: método de pesquisa para a incorporação de 
evidências na saúde na enfermagem. Texto Contexto Enferm. 2008;17(4):758-64.

9. Ursi ES. Prevenção de lesão de pele no perioperatório: revisão integrativa da literatura. [dissertação de mestrado]. Ribeirão Preto (SP): Escola de Enfermagem de Ribeirão Preto da Universidade de São Paulo, Ribeirão Preto; 2005.128p.

10. Polit DF, Beck CT, Hungler BP. Fundamentos de pesquisa em enfermagem: métodos, avaliação e utilização. 5. ed. Porto Alegre (RGS): Artmed, 2004. p. 487

11. Melnyk BM, Fineout-Overholt E. Making the case for evidence-based practice and cultivating a spirit of inquiry. In: Melnyk BM, Fineout-Overholt. Evidencebased practice in nursing \& healthcare. A guide to best practice. Philadelphia: Wolters Kluwer, Lippincott Williams \& Wilkins; 2011.p.3-24.

12. Gelber $S$, Coates AS, Goldhirsch A, CastiglioneGertsch M, Marini G, Lindtner J, et al. Effect of pregnancy on overall survival after the diagnosis of early-stage breast cancer. J Clin Oncol. 2001;19(6):1671-5.

13. Mottola-Junior J, Berrettini-Junior A, Mazzoccato C, Laginha F, Fernandes CE, Marques JA. Câncer de mama associado à gravidez: um estudo caso/controle. Rev Bras Ginecol Obstet.2002;24(9):585-91.

14. Reed W, Hannisdal E, Skovlund E, Thoresen S, Lilleng P, Nesland JM. Pregnancy and breast cancer: a populationbased study. Virchows Arch. 2003;443(1):44-50.

15. Aziz S, Kayani N, Israr M, Rahbar M, Pervez S, Khan $S$, et al. Case control study of novel prognostic markers and disease outcome in pregnancy/lactation-associated breast carcinoma. Pathol Res Pract.2003;199(1):15-21. 16. Makgasa M, Prichard RS, Malone C, Kerin MJ. Pregnancy associated breast cancer. Ir Medical $\mathrm{J}$. 2009;102(10):314-17.

17. Halaska MJ, Pentheroudakis G, Strnad P, Stankusova $\mathrm{H}$, Chod J, Robova HMD, et al. Presentation, management and outcome of 32 patients with pregnancy-associated Breast cancer: a matched controlled study. The Breast J. 2009;15(5):461-67.

18. Beadle BM, Woodward WA, Middleton LP, Tereffe W, Strom EA, Litton JK, et al. The impact of pregnancy on breast cancer outcomes in women $<35$ Years. Cancer 2009; 115(6):1174-84.

19. Peralta Musre O. Cáncer de mama y embarazo. Rev Chil Obstet Ginecol.2001;66(1):68-73.

20. Hill A, Dijkstra B, Healy CM, Kelly LM; Mcdermott EW, O'Higgins, N. Pregnancy-associated breast cancer. Ir Medical J. 2002;95(2):51-2, 54.

21. Grossmann R, Zettler CG, Saccozzi R, Grossmann S. Avaliação dos fatores prognósticos e preditivos de associação no câncer mamário durante a gestação. Rev
Bras Mastologia 2002; 12(2):23-7.

22. Martínez-Ramos D, Ferraris C; Greco M, Grosso I, Conti AR. Carcinoma de mama durante el embarazo. Cir Esp. 2007;82(5):305-7.

23. Khairy GA, Al-Abdulkarim HA. Breast carcinoma during pregnancy. Saudi Med J. 2008;29(11):1662-65.

24. Loibl S, Von Minckwitz G, Gwyn K, Ellis P, Blohmer JU; Schlegelberger $B$, et al. Breast carcinoma during pregnancy. International recommendations from an expert meeting. Cancer 2006;106(2):237-46.

25. Von Schoultz E, Johansson H, Wilking N, Rutqvist LE. Influence of prior and subsequent pregnancy on breast cancer prognosis. J Clin Oncol. 1995;13(2):430-4.

26. Lyons TR, Schedin PJ, Borges V. F. Pregnancy and breast cancer: when they collide. J Mammary Gland Biol Neoplasia 2009;14(2):87-98.

27. Kettelhut JC, Modena MAB. Câncer de mama e gestação Rev Fac Ciênc Med.2008;10(4):1-4.

28. Rossouw JE, Anderson GL, Prentice RL, Lacroix AZ, Kooperberg C, Stefanick ML, et al. Risks and benefits of estrogen plus progestin in healthy postmenopausal women: principal results from the Women's Health Initiative randomized controlled trial. JAMA 2002;288(3):321-33.

29. Daling JR, Malone KE, Doody DR, Anderson BO, Porter PL. The relation of productive factors to mortality from breast cancer. Cancer Epidemiol Biomarkers Prev. 2002;11(3):235-41.

30. Jacobsen BM, Schittone SA, Richer JK, Horwitz KB. Progesterone-independent effects of human progesterone receptors in estrogen receptor-positive breast cancer. Mol Endocrinol.2005;19(3):574-84.

31. Vousden K. P53 and prognosis: news insights and further complexity. Cell. 2005;120(1):7-10.

32. Melinda A, Maggard MD, Jessica B, O'Connell MD, Karen E, Lane MD, et al. Do young breast cancer patients have worse outcomes? J Surgical Research 2003;113(1):109-13.

33. Azad G K, Ring AE. Breast cancer and pregnancy. Breast Cancer Online 2007;10(10):1-5.

34. Brasil. Ministério da Saúde. Secretaria de Atenção à Saúde. Departamento de Ações Programáticas Estratégicas. Área Técnica de Saúde da Mulher. Pré-natal e Puerpério: atenção qualificada e humanizada - Manual técnico. Brasília (DF): Ministério da Saúde, 2005. 158p. 35. Lima AP, Teixeira RC, Corrêa ACP, Oliveira QC. Câncer de mama e de colo uterino no período gestacional: uma revisão de literatura. Ciênc Cuid Saúde 2009;8(4):699706.

Received: Jan. 18 2011 Accepted: Ago. 15 2011 